\title{
The Impact of European Economic Integration on Migration in the European Union
}

\author{
Mihaela SIMIONESCU, \\ Institute for Economic Forecasting, Bucharest \\ Centre for Migration Studies in Prague Business School, Prague \\ e-mail: mihaela_mb1@yahoo.com
}

\begin{abstract}
The recent enlargement of the EU (since 2004) and the United Kingdom's decision to leave the European Union have prompted a growing research interest in the political and academic environment because of the causes and consequences of migration between the CEE countries and those in the Western Europe. In this study, the effects of European economic integration on the number of EU-15 immigrants from the newly integrated EU countries were assessed by econometric techniques. According to panel data models, in the period 2000-2015, the number of migrants from the new member states of the EU has increased, in average, with more than 2200 people only due to their EU membership. This result reflects the positive impact of European economic integration on the number of emigrants from the CEE countries that chose the EU-15 states as destination countries. Moreover, according to some ridge Bayesian regressions, during the period 2004-2015, the EU-15 immigrants coming from the EU-13 states did not negatively affect the economic growth of the EU-15 countries.
\end{abstract}

Keywords: economic integration, migration, European Union, free movement

JEL Classification: F15, C53

\section{Introduction}

The context that favoured East-West migration within the EU is highlighted by: high income gaps between the old EU Member States and those that joined in 2004, 2007 and 2013, new Member States having a fairly high level of the population and supporting numerous transformations of society in order to achieve a functioning market economy and a free society. In the case of economic integration, four freedoms specific to the Single European Market are considered: the free movement of capital, people, goods and services. In this context, as Ebell and Warren (2016) show, EU membership has had a positive 
impact on the number of immigrants established in the EU-15 and coming from the new Member States due to labour mobility.

This paper aims to analyze the impact of European economic integration on emigrants from CEE countries that choose as target developed EU-15 countries. The novelty of the research is given by the actuality of the topic in the international context that is currently wrought by uncertainty about the consequences of Brexit, but also by questioning the positive effects of integration into the EU, going to pessimistic scenarios that anticipate the dissolution of the EU.

The methodology used to achieve the objectives is represented by panel data models, both for the fact that the series of data for CEE migration countries are short, as well as to highlight the impact of European economic integration on emigrants in these countries in a global approach.

The paper makes a description of the literature on migration in CEE countries in the context of European economic integration. After a brief presentation of the methodology, the empirical results based on the assessment of the impact of European economic integration on the number of EU-15 immigrants from the newly integrated EU countries are described. The article ends with a section of conclusions which highlights the results of the research and anticipates new directions for further analysis, starting from the limits of this research.

\section{Literature Review}

Since the early 1990s, Central and Eastern European countries have experienced the transition from the communist regime to a democratic state with a market economy. Against the backdrop of these changes, transformations in migratory behavior have also been observed. Until 1990, in all the countries in the region, migration was severely limited. There was only a limited period of exodus from rural to urban areas within the same country in the 1950s. The main reason was finding a job in large industrial centers. However, international labour migration was controlled by governments and did not go beyond the countries of Central and Eastern Europe. Migration was on a very limited scale and took only a few forms: the repatriation of ethnic minorities, family reunions or strictly controlled movements of workers. Since the early 1990s, the intensity of migratory movements has sharply increased, and migration between Central and Eastern European countries has also intensified. Migration patterns have diversified: from labour migration to forced migration of refugees and those seeking asylum. Some countries in the Central Eastern European region recorded 
for the first time in their post-war history, after the 1990s, some forms of migration. Long-term migration began to dominate.

Studies in the literature noted problems with the quality of data on the migration phenomenon. Data incompleteness and inconsistency can be caused by different reasons, including various reporting mechanisms or the use of distinct definitions. For example, according to the definition of the United Nations (UN), a long-term migrant is a person who established in a country other than the country of residence for a minimum period of one year. In other countries, such as Romania, Slovakia and the Czech Republic, official statistics provide data for permanent migrants, without an operational definition (Bijak et al., 2004). Therefore, for CEE countries, the discrepancy between indicators and data is a more important issue than for developed countries that already have a tradition in emigration and immigration.

Since the accession of the CEE countries to the EU, the labour market has become more attractive, even under the conditions of many labour-related and residence-related regulations. Temporary immigration is dominant for the CEE region, although Iglicka and Ziolek-Skrzypczak (2010) have shown that there have been cases where regulation has influenced the settlement decisions in a country (Armenians and Ukrainians in Poland have demanded permanent residence in Poland). According to Drbohlav et al. (2009), the Czech Republic has become an immigrant country for legal and illegal workers with unskilled, manual and subpaid jobs. Economic reasons remain the most important after EU accession in attracting migrants from the CEE countries.

Over the past 15 years, East-West migration has had various motivations. Typical migrants are those coming from rural areas where the only source of income is the one obtained abroad, but they do not just work to support their family in the country of origin. The number of urban, qualified, young (20-30 years) and often unmarried people who left the CEE countries for the EU-15 increased. Many Polish citizens emigrated to the UK and Ireland because these countries have opened up their labour markets. Fihl and Kaczmarczyk (2009) characterized Eastern-West migration as more regulated, less clandestine and irregular, more long-term than circular and more individualistic than that related to family strategies. Unlike the previous period, when the reasons were related to the problems of the economy transition and the pressure of poverty, after the accession to the EU, the migrants were animated by the desire for a better life, with structural changes in the group of emigrants from CEE countries. 
Boeri and Brücker (2000) analyzed the effects of economic integration on the goods and factors markets in the EU Member States. According to the authors' analysis, greater openness in trade will exert little influence on wages and employment, limiting to labour-intensive industries in some regions at the border with new entrants to the EU. In terms of migration, very slow convergence in GDP per capita stimulates migration to older EU member states once barriers to labour migration from CEE countries have been eliminated. Boeri and Brücker (2000) anticipated that the maximum level of migration would be reached in 30 years after the integration of CEE states, but migrants in these states would not exceed $1.1 \%$ of the EU-15 population.

Sinn (1999) proposed a theoretical model for capital and labour migration based on the experience of German unification. The author believes that the migration of new EU members to EU-15 countries will be temporary due to objective reasons such as: high living costs outside the country of origin, higher rents, discomfort of not living in the country of origin and high costs to return home.

The econometric model proposed by Andrle et al. (2015) assesses the impact of migration on the real economy through 3 channels: the private sector, external competitiveness and the public sector. Labour emigration and remittances affect the public sector by diminishing investment and consumption, which are only partially offset by remittances. External competitiveness is affected by wage increases and exchange rate appreciation, and the public sector is influenced by inducing policies to increase labour income taxes. Simulations based on the model of Andrle et al. (2015) indicates a continuation of the increase in net migration flows between 2015-2030 in the EEAS area, which is consistent with the United Nations and Eurostat estimates.

The literature on the link between EU enlargement in 2004 and 2007 and the UK response shows that the decision to immigrate to CEE nationals is related to job search. Initially, the emigration decision is a voluntary one and a desire for temporary settlement, but over time the decision can become in favour of permanent emigration. Migrants from the CEE countries intend to stay for a few weeks or months, unlike non-EU citizens (Galgóczi et al., 2009).

The United Kingdom was one of the supporting countries of the EU enlargement in 2004 and was among the few countries that did not impose restrictions on receiving migrants from CEE countries (Cini and Borragán, 2013). Recent studies in literature confirm the media position against immigrants (Spoonley and Butcher, 2009, Robinson et al., 2010, Leveson, 2012, Esses and Medianu, 2013, Spigelman, 2013, Drzewiecka et al., 2014). Spigelman (2013) 
showed that the negative image of the 2004-2008 Polish immigrants is contrary to reality. Esses and Medianu (2013) suggest that the negative and exaggerated image of immigrants and refugees in the UK goes right up to dehumanization.

\section{Methodology}

In this study, we will use panel data models to explain the number of emigrants from new Member States countries to the EU-15. Below, a brief description of the panel models will be made.

It is assumed that a continuous dependent variable is in a relation of linear dependence with a set of predictors. If there is a set of individuals or units for which these variables are measured, Allison (2009) shows that the model can be written in the following form: $y_{i t}=\mu_{t}+\beta \cdot x_{i t}+\gamma \cdot z_{i}+\alpha_{i}+\varepsilon_{i t}$.

$\mu_{t^{-}}-$intercept, which may vary from one period to another, but does not change from one unit to another

$x_{i t}$ - independent variables that may vary over time, but also from one unit to another

$Z_{i^{-}}$- independent variables whose values do not change over time (stable characteristics)

\section{$\beta, \gamma$ - coefficients of independent variables}

In the above-mentioned form, the model is based on the hypothesis that the effects are invariant in time (the effects are the same at different times).

$\varepsilon_{i t}$-error, different for each unit at each time

$\alpha_{i}$ - error, which varies only from one unit to another, not over time.

Hypotheses on the error term $\alpha_{i}$ help determine the type of model using panel data. The error terms should not be correlated with the explanatory variables in the model, but this hypothesis is violated if relevant variables have been omitted from the model. If errors $\alpha_{i}$ are correlated with $x_{i t}$, the pattern is fixed. The Fixed Effect method controls invariant variables over time that cannot be measured, but which influence the dependent variable. If the effects of invariant variables over time can be controlled, they cannot be estimated; therefore, $\gamma$ cannot be estimated. If the errors $\alpha_{i}$ are not correlated with $x_{i t}$ (no relevant variables have been omitted over time, the omitted variables are not correlated with the variables in the model), the random model can provide 
unbiased estimators for $\beta$ and $\gamma$ and generally with standard errors lower than those in the fixed effects model.

The Lagrange Breusch-Pagan multiplier test helps us decide whether to use an OLS regression or a model with random effects. The null hypothesis of the test is that the variance across units is 0 (there are no significant differences between units, that is, no panel effect).

Starting from the following models:

$$
\begin{aligned}
& Y_{i t}=\alpha+X_{i t}^{1} \cdot \beta_{1}+\cdots+X_{i t}^{K} \cdot \beta_{K}+\varepsilon_{i t} \\
& Y_{i t}=\alpha+X_{i t}^{1} \cdot \beta_{1}+\cdots+X_{i t}^{K} \cdot \beta_{K}+\mu_{i}+v_{i t} \\
& i=1,2, \ldots, N \text { și } j=1,2, \ldots, T
\end{aligned}
$$

$\mathrm{Y}_{\mathrm{it}}-$ dependent variable for unit $\mathrm{i}$ and at time $\mathrm{t}$

$\mathrm{X}_{\mathrm{it}}^{\mathrm{j}}$ - the regressor $\mathrm{j}$ for unit $\mathrm{i}$ and at time $\mathrm{t}, \mathrm{j}=1,2, . ., \mathrm{K}$

$\alpha$-intercept

$\mu_{\mathrm{i}}$ - individual invariant effects over time

$\varepsilon_{\mathrm{it}}, \mathrm{v}_{\mathrm{it}}$ - Different error terms for each unit at each time

The Fixed Effect Model is written:

$$
\mathrm{Y}_{\mathrm{it}}=\alpha+\mathrm{X}_{\mathrm{it}}^{1} \cdot \beta_{1}+\cdots+\mathrm{X}_{\mathrm{it}}^{\mathrm{K}} \cdot \beta_{\mathrm{K}}+\mu_{\mathrm{i}}+\mathrm{v}_{\mathrm{it}}
$$

The assumptions relevant to the fixed-effect model are: the unobservable individual effects are represented by the unobserved parameters, the explanatory variables in $X$ are independent of the idiosyncratic $v_{i t}$ but are not independent of the individual fixed effects, the idiosyncratic error $v_{i t}$ is independent and identically distributed iid $\left(0, \sigma_{v}^{2}\right)$. If there is only one independent variable, the form of the model is:

$$
\mathrm{Y}_{\mathrm{it}}=\alpha+\mathrm{X}_{\mathrm{it}} \cdot \beta+\mu_{\mathrm{i}}+\mathrm{v}_{\mathrm{it}}
$$

The mean over time is calculated as follows: $\bar{Y}_{i .}=\alpha+\bar{X}_{i} \cdot \beta+\mu_{i}+\bar{v}_{i}$. The difference between the two previous equations is:

$$
\mathrm{Y}_{\mathrm{it}}-\overline{\mathrm{Y}}_{\mathrm{i} .}=\left(\mathrm{X}_{\mathrm{it}}-\overline{\mathrm{X}}_{\mathrm{i}}\right) \cdot \beta+\left(\mathrm{v}_{\mathrm{it}}-\overline{\mathrm{v}}_{\mathrm{i}} \cdot\right)
$$


This internal transformation is the basis for the fixed-effect estimator. By applying the least squares method in the last equation, we obtain the $\beta$ estimators for fixed effects. The random-effects model is written:

$$
\mathrm{Y}_{\mathrm{it}}=\alpha+\mathrm{X}_{\mathrm{it}}^{1} \cdot \beta_{1}+\cdots+\mathrm{X}_{\mathrm{it}}^{\mathrm{K}} \cdot \beta_{\mathrm{K}}+\mu_{\mathrm{i}}+\mathrm{v}_{\mathrm{it}}
$$

The hypotheses relevant to the random effect model are: the unobservable individual effects are $\mathrm{iid}\left(0, \sigma_{\mu}^{2}\right)$, the explanatory variables in $\mathrm{X}$ are independent of the idiosyncratic $v_{i t}$, but independent of individual random effects $\left(\operatorname{cov}\left(X_{i t}^{K}, \mu_{i}\right)=0\right)$, the idiosyncratic error $\mathrm{v}_{\mathrm{it}}$ is independent and identically distributed $\operatorname{iid}\left(0, \sigma_{v}^{2}\right)$.

4. Measuring the impact of European economic integration on the number of emigrants in the Central and Eastern European countries

The number of migrants from the A8 countries, Bulgaria, Romania and Croatia, that chose one of the EU-15 countries in 2000-2015, is considered. A dummy variable (EU member) is defined and it takes the value 1 if the analyzed CEE country was an EU member in a given year of that period. Otherwise, the dummy variable is 0 . The control variables are the real GDP growth rate and the unemployment rate in the migrants' home countries. The purpose of the analysis is to identify the impact (positive or negative) on the emigration of migrants' home countries in the EU, considering only the developed EU-15 countries as destination countries. Data series for macroeconomic variables are provided by Eurostat. 
Figure 1. Number of migrants from the A8, Bulgaria, Romania and Croatia to the EU-15

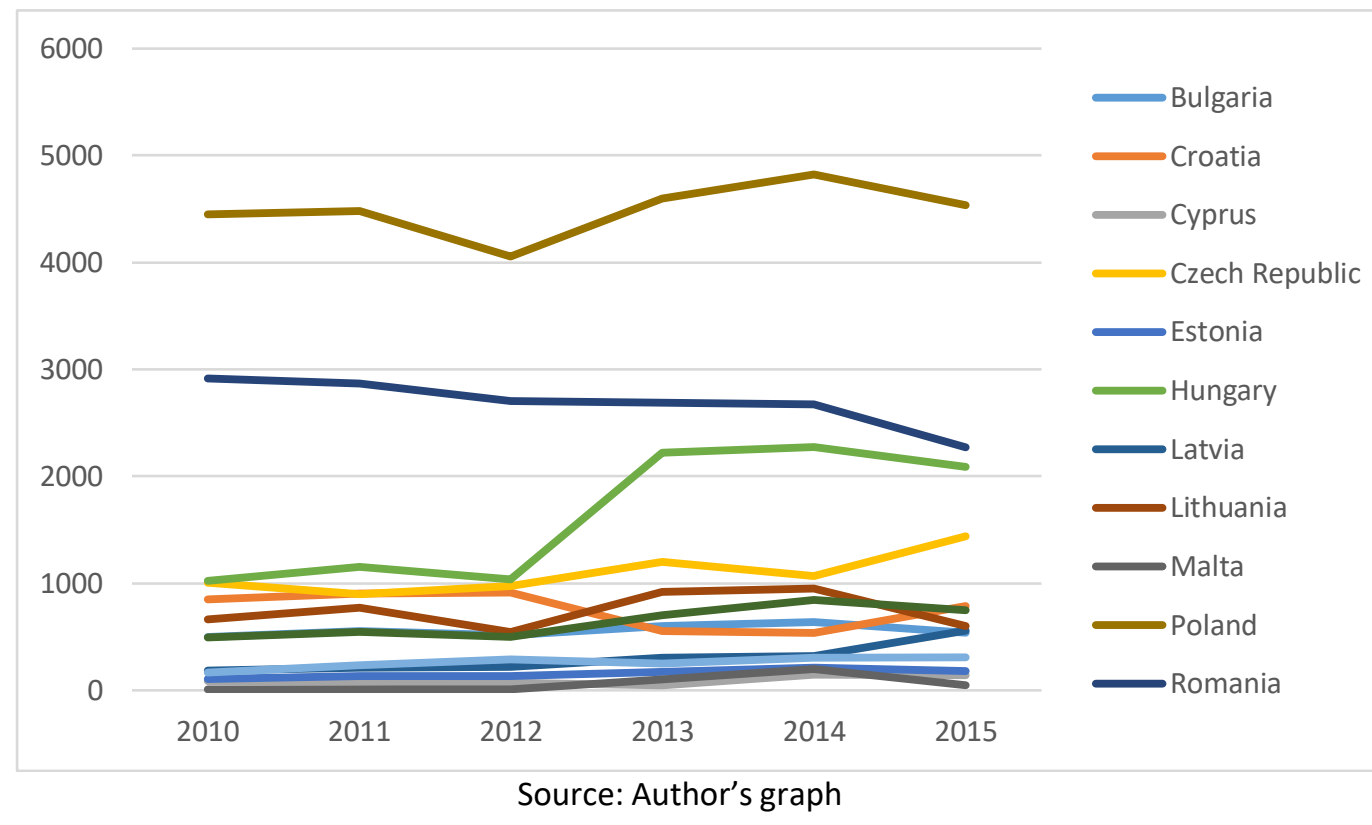

As can be seen from the chart above, since 2007, Romania has sent most migrants to the EU-15 countries on the background of its integration into the EU, ahead of Poland, which until then was a leader in the CEE countries. Currently, most Romanian emigrants are in Italy, followed by Spain. A significant presence of Romanian immigrants in Italy has been observed since 1999 when $80 \%$ of Romanian emigrants to the EU chose Italy and Spain as destination countries and because the languages of these countries are similar to Romanian. A new wave of migration to Italy was noticed at the beginning of 2002, when Romanian citizens were given the right to arrive in any Schengen country without a visa. As in Italy, in Spain, the Romanians represent the largest group of immigrants. Against the backdrop of the economic problems generated by the economic and financial crisis, including high unemployment rates, as of 2012, many Romanians left Spain, so that most Romanians living abroad live in Italy.

First check the stationary of panel data based on the Levin-Lin-Chu test at a significance level of $5 \%$. The null hypothesis of the test determines that there are unit root roots in the panel, and the alternative hypothesis fixes that the panels are stationary. 
Table 1. Results of the Levin-Lin-Chu test for verifying static data in the panel

\begin{tabular}{ccc}
\hline Variable & Statistics & p-value \\
\hline Emigrants & -3.4825 & 0.0002 \\
Real GDP rate & -4.9046 & 0.000 \\
Unemployment rate & -6.6966 & 0.000 \\
\hline
\end{tabular}

Source: own calculations

According to the Levin-Lin-Chu test, all variables are stationary in the panel at a significance level of $5 \%$.

Table 2. Dynamic panel to explain the number of migrants from the A8, Bulgaria, Romania and Croatia to the EU-15

\begin{tabular}{cccc}
\hline Variable & Coefficient & $\mathbf{z}$ & $\mathbf{P}>|\mathbf{z}|$ \\
\hline Emigrants in previous & 0.69728 & 0.0459 & 0.000 \\
year & & & \\
Real GDP rate & 3075.838 & 5.18 & 0.000 \\
Unemployment rate & 3466.736 & 4 & 0.000 \\
EU member & 23892.95 & 3.57 & 0.000 \\
Constant & -52204.72 & -4.4 & 0.000 \\
\hline
\end{tabular}

Source: own calculations

According to the linear dynamic panel model with Arellano-Bover / Blundell-Bond estimators, EU membership has had a positive and statistically significant impact on the number of migrants sent to EU-15 countries. Practically, between 2000 and 2015, the number of migrants in the countries surveyed increased, on average, by 23,893 people only due to their EU membership status at one time. With an increase in the unemployment rate by one percentage point in the countries of origin, the number of emigrants increased, on average, between 2000 and 2015 by 3467 people. Although the GDP rate has increased in these countries of origin, the number of migrants continued to grow, perhaps also because the slight economic growth did not immediately reflect in a better standard of living. 
Table 3. Fixed-effect panel model to explain the number of migrants from the A8, Bulgaria, Romania and Croatia to EU-15 countries

\begin{tabular}{llll}
\hline Variable & Coefficient & $\mathbf{Z}$ & $\mathbf{P}>\mathbf{z} \mid$ \\
\hline Real GDP rate & 1398.341 & 2.24 & 0.026 \\
EU member & 22881.26 & 3.8 & 0.000 \\
Constant & 13738.2 & 2.52 & 0.013 \\
\hline
\end{tabular}

Source: Author's calculations

$69.14 \%$ of the change in the number of migrants is explained by the differences between the panels. According to the fixed-effects panel model, between 2000 and 2015, the number of migrants in the analyzed countries increased on average by 22882 people only due to the EU membership status at one time. Estimates based on both models show the positive impact of European economic integration on the number of migrants from the CEE countries to the EU-15. The results are in line with expectations but also with previous studies (Estevão and Tsounta, 2011; Jaumotte and Buitron, 2015; Atoyan et al., 2016), but so far there is no advanced research in the literature to measure accurately this type of impact.

According to a Bayesian-type ridge regression that assesses the impact of EU-13 immigrants on real economic growth in the EU-15 over the period 20042015, there was a positive, but insignificant impact of immigrants. So, they do not negatively influence output in the developed states, the influence is positive, but insignificant (the posterior probability for a standardized parameter is close to 1 , at a standard deviation of 0 is 0.663 , greater than 0.5 ). The results are presented in Appendix 1.

\section{Conclusions}

The recent enlargement of the EU (since 2004) determined a growing interest in the political and academic environment in terms of the causes and consequences of migration between the CEE countries and those in the Western Europe.

Given that there is no research in the literature in order to evaluate the positive impact of the European economic integration of the new EU Member States in terms of the relationship with the EU-15 countries, in this study we 
measured the impact of EU integration of the new Member States from the perspective of citizens migration to the developed EU countries. This type of analysis is more important knowing that the United Kingdom has decided to leave the EU because of immigrants from the CEE countries. Considering the contagion effect, other countries may also make this decision.

In this study, according to panel models, between 2000 and 2015, the number of migrants in the new Member States increased by an average of more than 2200 people only due to the EU membership status at one time. So, the result shows the positive impact of European economic integration on the number of emigrants from the CEE countries to the EU-15. Moreover, since 2004, EU-15 immigrants from the EU-13 did not negatively affect the economic growth of EU-15 countries.

This empirical assessment of the consequences of EU integration only refers to the EU-15 countries as destination countries, as migrants chose these countries, with the exception of the Czech Republic that has become an important receiver of migrants. However, bilateral migration flows between all EU countries have not been taken into account. In a future research, it would be useful to consider migratory flows using gravity models.

\section{Appendix 1}

Estimations of marginal posterior distribution

$\begin{array}{lccccccc}\text { Covariate } & \text { SD } & \text { PP1SD } & 25 \% & 75 \% & 2.5 \% & 97.5 \% & \text { b } \\ \text { Intercept } & 0.000 & 1.000 & 0 & 0 & 0.000 & 0.000 & 1.192 \\ \text { Immigrants } & 0.001 & 0.663 & 0 & 0 & -0.001 & 0.001 & 0.000\end{array}$

\section{References}

[1] Allison, P. D. (2009). Fixed effects regression models. New York: SAGE publications.

[2] Andrle, M., Blagrave, P., Espaillat, P., Honjo, K., Hunt, B., Kortelainen, M., \& Mursula, S. (2015). The Flexible System of Global Models-FSGM. IMF Working Paper 15/64, pp. 1-66.

[3] Atoyan, M. R., Christiansen, L. E., Dizioli, A., Ebeke, M. C., Ilahi, M. N., Ilyina, M. A., \& Raei, M. F. (2016). Emigration and its economic impact on Eastern Europe. IMF Staff Discussion Note, pp. 1-48. 
[4] Bijak, J., Kupiszewski, M. and Kicinger, A. (2004). International migration scenarios for 27 European countries, 2002-2052. CEFMR Working Paper (Warsaw), pp. 1-69.

[5] Boeri, T., \& Brücker, H. (2005). Why are Europeans so tough on migrants?. Economic Policy, pp. 630-703.

[6] Drbohlav, D. (2005) The Czech Republic: from liberal policy to EU membership, Retrived from http://www.migrațiainformation.org/Profiles/display.cfm?ID=325

[7] Drzewiecka, J. A., Hoops, J. F., \& Thomas, R. J. (2014). Rescaling the state and disciplining workers in discourses on EU Polish migration in UK Newspapers. Critical Studies in Media Communication, pp. 410-425.

[8] Esses, V. M., Medianu, S., \& Lawson, A. S. (2013). Uncertainty, threat, and the role of the media in promoting the dehumanization of immigrants and refugees. Journal of Social Issues, pp. 518-536.

[9] Fihel, A. \& P. Kaczmarczyk (2009) 'Migrația: a threat or a Chance? Recent migrația of Poles and its impact on the Polish labour market', in Burrell, K. (ed.) Polish migrația to the UK in the 'new' European Union: after 2004. England: Ashgate.

[10] Galgóczi, B., Leschke, J., \& Watt, A. (2009). Intra-EU labour migration: Flows and policy responses. Béla Galgóczi, B., Leschke, J. \& Watt, A.(eds.), pp. 1-28.

[11] Iglicka, K. \& Ziolek-Skrzypczak, M. (2010). EU membership highlights Poland's migrația challenges, Retrived from http://www.migrațiainformation.org/feature/display.cfm ?ID=800.

[12] Leveson, N. G. (2012). Complexity and safety. In Complex Systems Design \& Management. Berlin Heidelberg: Springer.

[13] Robinson, W. D., Bowlin, M. S., Bisson, I., Shamoun-Baranes, J., Thorup, K., Diehl, R. H., \& Winkler, D. W. (2010). Integrating concepts and technologies to advance the study of bird migration. Frontiers in Ecology and the Environment, pp. 354-361.

[14] Sinn, H. W. (1999). EU Englargement, Migration and Lessons from German Unification. Cesifo Working Papers, pp. 1-23.

[15] Spigelman, A. (2013). The depiction of Polish migrants in the United Kingdom by the British press after Poland's accession to the European Union. International Journal of Sociology and Social Policy, pp. 98-113.

[16] Spoonley, P., \& Butcher, A. (2009). Reporting superdiversity. The mass media and immigration in New Zealand. Journal of Intercultural Studies, pp. 355-372. 